\title{
Effects of the cationic structures of fluorohydrogenate ionic liquid electrolytes on the electric double layer capacitance
}

\section{AUTHOR(S):}

Senda, Atsushi; Matsumoto, Kazuhiko; Nohira, Toshiyuki; Hagiwara, Rika

\section{CITATION:}

Senda, Atsushi ... [et al]. Effects of the cationic structures of fluorohydrogenate ionic liquid electrolytes on the electric double layer capacitance. Journal of Power Sources 2010, 195(13): 4414-4417

ISSUE DATE:

2010-07-01

URL:

http://hdl.handle.net/2433/109741

\section{RIGHT:}

(c) 2010 Elsevier; この論文は出版社版でありません。引用の際には出 版社版をご確認ご利用ください。; This is not the published version. Please cite only the published version. 


\title{
Supplementary content
}

Effects of the cationic structures of fluorohydrogenate ionic liquid

\author{
electrolytes on the electric double layer capacitance
}

Atsushi Senda, Kazuhiko Matsumoto, Toshiyuki Nohira, Rika Hagiwara*

Graduate School of Energy Science, Kyoto University, Sakyo-ku, Kyoto 606-8501, Japan

* E-mail: hagiwara@energy.kyoto-u.ac.jp, Tel: +81-75-753-5822, Fax: +81-75-753-5906 


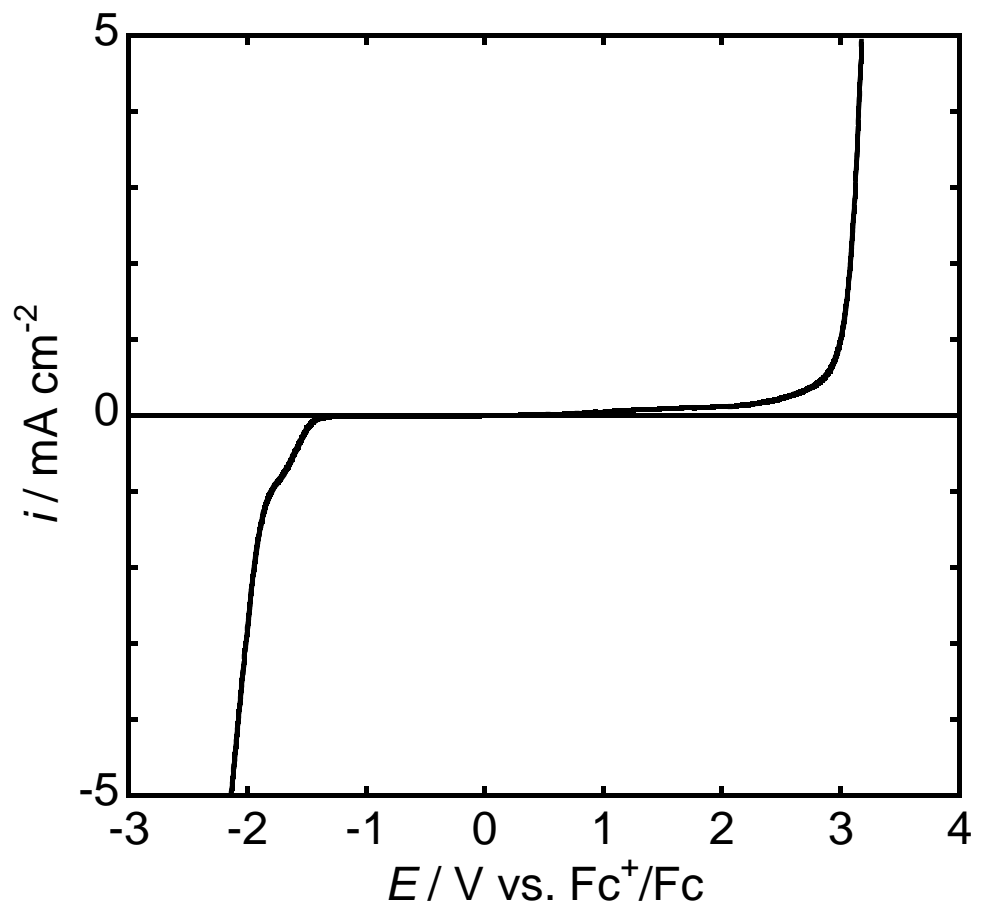

Fig. S1 Linear sweep voltammogram of a glassy carbon electrode in MOMMPyr $(\mathrm{FH})_{2.3} \mathrm{~F}$. Scan rate: $10 \mathrm{mV} \mathrm{s}^{-1}$, counter electrode: a glassy carbon rod, reference electrode: Ag wire immersed in $\mathrm{EMImBF}_{4}$ containing $0.05 \mathrm{M}$ of $\mathrm{AgBF}_{4}$. The potential is referenced to the redox potential of ferrocenium/ferrocene couple. 